\title{
A STUDY OF SPRING WATER QUALITY AND ITS SUITABILITY FOR DIFFERENT USES IN THE AREA OF BARTELLA - EASTERN MOSUL
}

\author{
Mohammed A. M. Sulaiman ${ }^{1}$ \\ Asaad A. M. AL-Hussein ${ }^{1}$ \\ Alaa S. Saleh \\ Ministry of Water Resources \\ General Commission for Groundwater \\ Mosul, Nineveh, Iraq, 41006 \\ ${ }^{1}$ Department of Geography \\ Education College \\ University of AL-Hamdaniya \\ Erbil road, Al- Hamdaniya District, Nineveh, Iraq, 41006
}

\begin{abstract}
The water of the three springs in the village of Tarjla (located in the area of Bartala, eastern Mosul) is characterized by different physical and chemical properties depending on the results of the laboratory tests of (NTU, EC, TDS, TH, PH) and major ions $\left(\mathrm{Na}^{+}, \mathrm{Ca}^{+2}, \mathrm{Mg}^{+2}, \mathrm{Cl}-, \mathrm{SO}_{4}^{-2}, \mathrm{CO}_{3}^{-2}+\mathrm{HCO}_{3}^{-}\right)$for six selected water samples for the study area. This difference did not remain constant, but changed with the flow of water to the neighboring villages (Sheikh Amir, Shaquli, Karemlesh), where the percentages of physical and chemical concentrations have changed in terms of the increase and decrease of some water samples. This is due to the time factor and the water contact of some of the soils and rocks that encountered their flow as well as exposure to the sun. The purpose of the research is to study the quality of springs water to determine its suitability for different uses. Using the Piper and Stiff classifications, the water quality is calcium-bicarbonate, the calcium ion predominates over the rest of the positive ions and the bicarbonate ion prevails over the rest of the negative ions, this indicates that spring number (1) and spring number (3) are derived from the Fat'ha formation deposits, which contain limestone and gypsum rocks that contain high concentrations of sulphates. The spring number (2) is derived from the Injana formation and modern sediments that is hydraulically connected with each other and can be considered one reservoir. By comparing the results of laboratory tests with the international standards, it was found that the water of spring number (2) is suitable for human use, and that the water of spring's number (1) and (3) are not suitable for human use because they contain a high proportion of sulfur ions. All water samples are suitable for agricultural and animal use and very good to excellent.
\end{abstract}

Keywords: Tarjla village, springs water, physical and chemical properties, water use.

DOI: $10.21303 / 2461-4262.2020 .001257$

\section{Introduction}

Geochemistry of groundwater is an important factor determining its use for domestic, irrigation and industrial purposes. Groundwater components change inside the ground during contact with rocks and minerals within the Aquifer, Water components are also affected by interactions with the environment, and water quality may provide important information about these environments that they interact with over time [1].

The quality control of natural spring water is of interest and is a priority action of government authorities. Raw water plays an essential role for drinking purposes and for other sanitary uses and industrial processes [2].

The research problem dealt with the decrease of fresh surface water in the study area, so the population turned to the use of spring's water because of the urgent need for it. The quality of spring's water is as important as its quantity or size, so it was necessary to define its specifications to show the degree of sweetness, salinity and contamination, and the question 
of studying its quality has become important in recent times in order to know its suitability for different uses.

The water of the three springs is used by the people of the four villages (Tarjla, Sheikh Amir, Shaquli, Karemlesh) mainly for household washing purposes and in agriculture and animal use and is not used for drinking purposes. Therefore, the aim of research is to determine the validity of the water of these eyes for different uses, depending on the field and laboratory data and compare them with high standards in order to reach the scientific facts. The aim of research is to study the quality of springs water to determine its suitability for different uses.

\section{Study area}

The boundaries of the study area are located in the area of Bartella which is administratively affiliated to Al-Hamdaniya district. It is bordered by Erbil governorate in the east, Mosul district to the west and Sheikhan district to the north, while the Makhmour district is bordered by the south.

The three springs water are located near the village of Tarjla, two springs converging in a concrete waterway with a width of half a meter and a height of one meter, extending for a distance of $6.25 \mathrm{~km}$, starts from the village of Tarjla passing through the village of Shaquli and ends at the village of Karemlesh, whose water is used for agricultural purposes. The third spring also forms a waterway but in the form of a valley extending for a distance of $1.24 \mathrm{~km}$ and starts from the village of Tarjla and ends at the village of Sheikh Amir (Fig. 1).

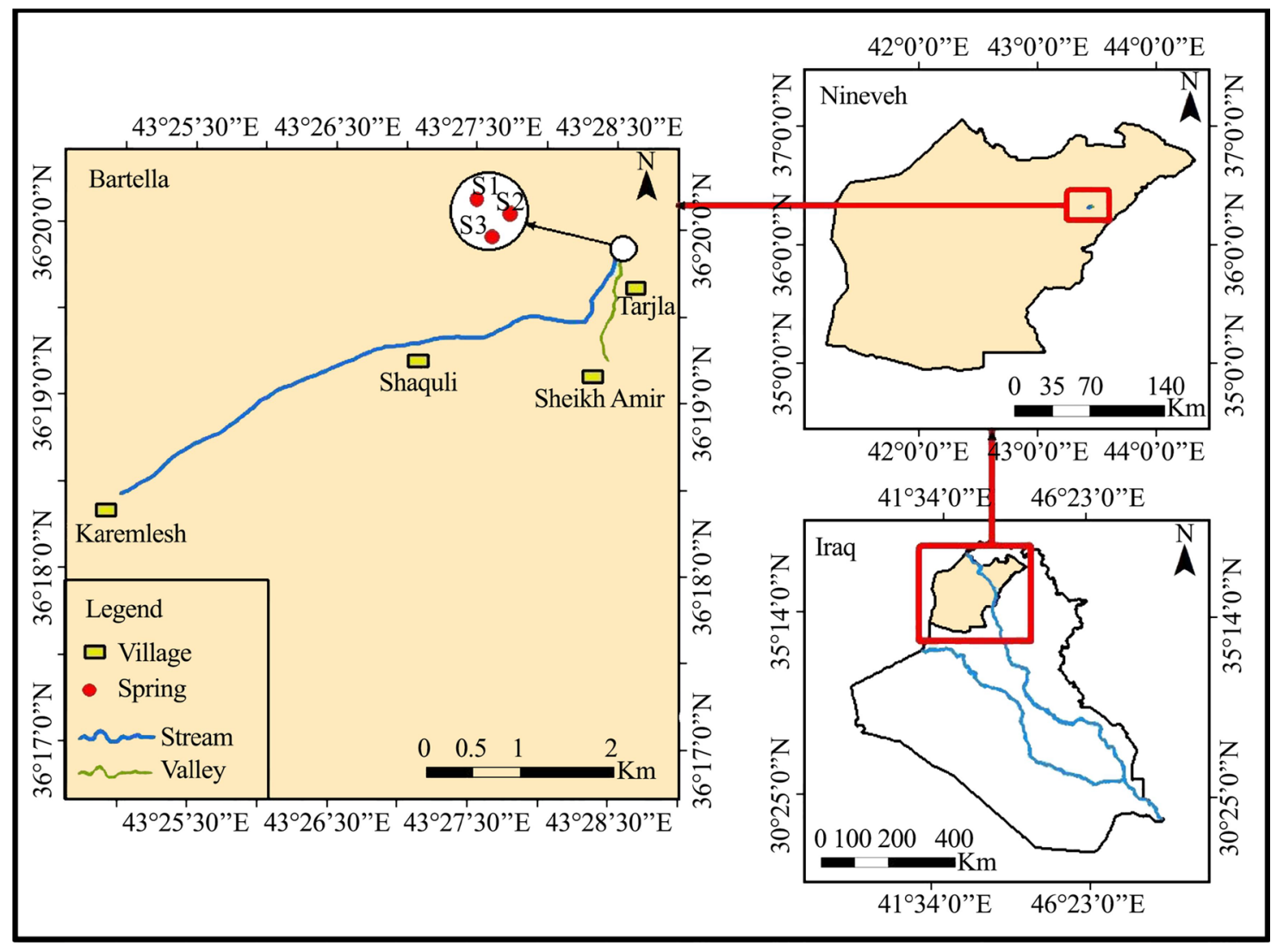

Fig. 1. Map of the study area

Fig. 1 shows the astrological boundary of study area lies between two latitudes $\left(36^{\circ} 19^{\prime} 59^{\prime \prime}\right.$ $\left.36^{\circ} 17^{\prime} 57^{\prime \prime}\right)$ north and longitudes (432 $\left.8^{\prime} 56^{\prime \prime}-43^{\circ} 24^{\prime} 22^{\prime \prime}\right)$ east.

Many research studies have been conducted on groundwater in the study area. The size of the geological formations that exist within the borders of the region was calculated using a 
three-dimensional computer model. It also explored the possibility of using this model to identify the thickness of geological layers containing groundwater and any point within the boundaries Study area [3]. In addition, Aquifers were studies and modeled and the conclusion was that the type of water reservoir in the Injana formation of the type of reservoir which is semi-confined to unconfined and is qualitatively acceptable as it can be used in human consumption but not for drinking. The water reservoir in the Pilaspi formation is of the type of the confined water reservoir, in addition to the good water quality that can be used for drinking, human uses and watering crops [4]. Further, some water springs in the study area were studies from a therapeutic point of view. It is concluded that spring water contains the necessary chemical elements in building the cells of the human body, as this water with the food diet contributes to compensating the body with an important percentage of the chemical elements that decrease from the body daily as a result of vital activities [5].

\section{Field and laboratory work}

A field survey of the area was conducted on (14/7/2018) to collect the ground facts and determine the locations of springs and villages (Tarjla, Shaquli, Shaikh Amir, Karemlesh), which pass through the waterway of the springs using the Global Positioning System (GPS). On August 8, 2018, six water samples were taken from different sites of the study area.

Some physical measurements of these samples were carried out in the laboratories of the Nineveh Water Directorate such as turbidity (NTU), temperature, electrical conductivity (E.C), total dissolved solids (TDS), total hardness (TH) and acidic function (PH). The chemical analysis of these water samples was carried out represented by positive ions (Cations) include sodium $\left(\mathrm{Na}^{+}\right)$, potassium $\left(\mathrm{K}^{+}\right)$, calcium $\left(\mathrm{Ca}^{+2}\right)$ and magnesium $\left(\mathrm{Mg}^{+2}\right)$, As well as negative ions (Anions) include chloride $\left(\mathrm{Cl}^{-}\right)$, sulphate $\left(\mathrm{SO}_{4}^{-2}\right)$, carbonates and bicarbonates $\left(\mathrm{CO}_{3}^{-2}+\mathrm{HCO}_{3}\right)$.

The various physical and chemical properties of water were evaluated by standard international methods [6] and compared with the results of the research to determine the validity of the spring water for different uses. It also used some important programs in the search (Arc GIs v10.3, RockWorks v17, Google earth pro, aquachem).

\section{Hydrogeology of study area}

Quaternary sediments, including modern sediments, cover most of the study area and because of the high permeability of these sediments, it helps to filter the surface water through it to the Fat'ha and Injana formations. The composition of Injana formation and modern sediments can be considered hydraulically related, and that modern sediments become thicker as move away from the Ein Al-Sefra fold near the study area, In general, the thickness of quaternary sediments is less than the thickness of the formation under which it is located.

The three springs water flowing from different geological formations, which are composed of conglomerate rocks with sediments of silt, sand, clay, limestone and dolomite rocks have different morphological and size characteristics, as well as sulfuric rocks, These deposits are characterized by permeability and high porosity. When there is rain fall on the drainage basin from which these springs rise, the water is highly filtered to the ground, and this will increase the water supply of these springs and thus increase their water flow.

\section{Samples analysis results}

As mentioned, six water samples were taken from different sites of the study area. Three samples are taken from three springs near the Tarjla village, and three samples from three villages (Sheikh Amir, Shaquli and Karemlesh) in order to see the impact of the duration of water flow on the quality (Table 1, Fig. 2, 3). Table 1 shows the results of physical and chemical analysis of these models.

Fig. 3 shows that the rates of negative ions (anions) of water samples are much higher than those of positive ions (cations), indicating that the water quality is close to carbonate sulfate. 
Table 1

Analytical results for the water samples collected from the springs and villages

\begin{tabular}{|c|c|c|c|c|c|c|}
\hline \multirow{3}{*}{$\begin{array}{l}\text { Parameters in } \mathrm{mg} / \mathrm{L} \\
\text { unless otherwise stated }\end{array}$} & \multicolumn{6}{|c|}{ Samples of sections } \\
\hline & \multicolumn{3}{|c|}{ Tarjla village } & \multirow{2}{*}{ Sheikh Amir village } & \multirow{2}{*}{ Shaquli village } & \multirow{2}{*}{ Karemlesh village } \\
\hline & Spring 1 & Spring 2 & Spring 3 & & & \\
\hline Turbidity (NTU) & 15 & 10 & 5.5 & 15 & 6 & 2.7 \\
\hline $\mathrm{PH}$ & 6.9 & 7.1 & 6.8 & 7.7 & 7.3 & 6.8 \\
\hline E.C $(\mu \mathrm{s} / \mathrm{cm}) /\left(25^{\circ} \mathrm{C}\right)$ & 1328 & 978 & 1480 & 1480 & 1161 & 1248 \\
\hline Т.H. & 552.3 & 516 & 632.5 & 630.2 & 552.2 & 548.7 \\
\hline T.D.S & 858 & 630 & 964 & 966 & 750 & 808 \\
\hline $\mathrm{Ca}^{+2}$ & 136 & 147 & 150 & 168 & 146 & 139 \\
\hline $\mathrm{Mg}^{+2}$ & 51.7 & 36.2 & 62.7 & 51.2 & 45.6 & 49 \\
\hline $\mathrm{Na}^{+}$ & 27 & 11.2 & 32 & 36 & 24 & 26 \\
\hline $\mathrm{K}^{+}$ & 3.5 & 1.6 & 4.3 & 4.7 & 3.1 & 3.4 \\
\hline $\mathrm{CaHCO}_{3}^{-}$ & 230 & 196 & 252 & 230 & 240 & 256 \\
\hline $\mathrm{SO}_{4}^{-2}$ & 290 & 284 & 342 & 268 & 273 & 280 \\
\hline $\mathrm{Cl}^{-}$ & 68 & 26 & 80 & 140 & 64 & 70 \\
\hline $\mathrm{CaCO}_{3}$ & 552 & 516 & 632 & 630 & 552 & 600 \\
\hline
\end{tabular}

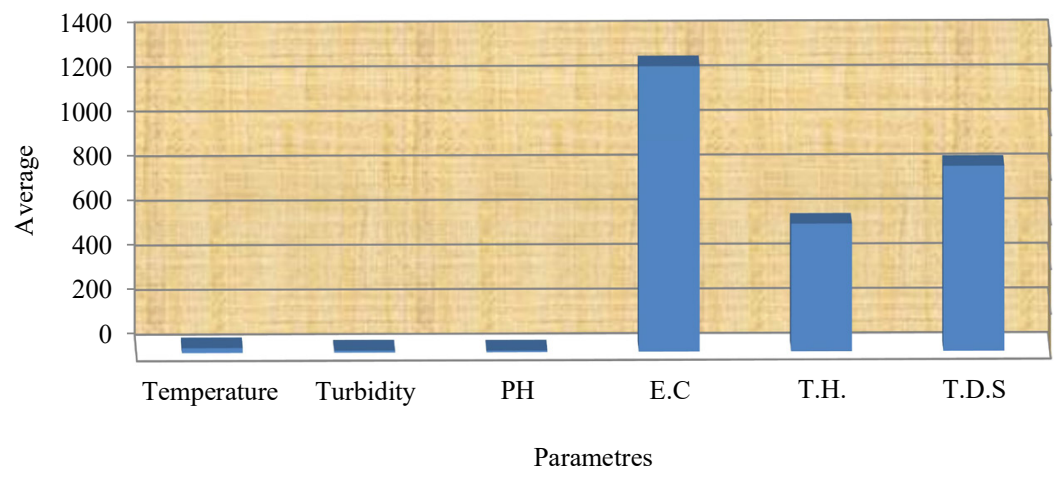

Fig. 2. Average of physical properties for water samples

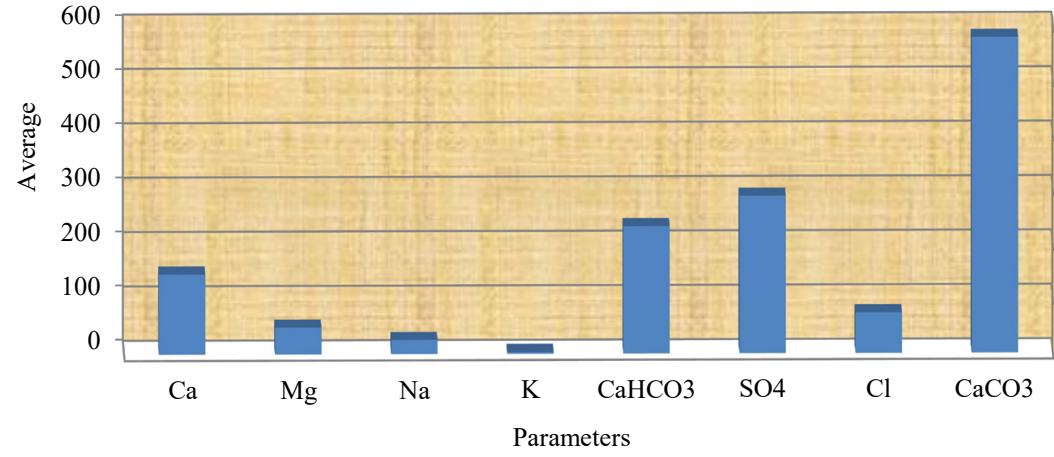

Fig. 3. Average of Chemical properties for water samples

\section{Physical and chemical properties of spring's water}

\section{1. Physical properties}

$\mathrm{PH}$ is defined as the negative logarithm of hydrogen ion concentration [7]. The $\mathrm{PH}$ was measured by (ECO Testr PH2). The PH value of all water samples from the study area was between (6.8-7.7), which shows a relative diffraction in the basal direction due to an 
increase in calcium and magnesium ions as well as ionic bicarbonate in this water. Electrical Conductivity (E.C) is defined as the portability $\left(1 \mathrm{~cm}^{3}\right)$ of the water to the electrical conduction at a temperature $\left(25^{\circ} \mathrm{C}\right)[8]$. The electrical conductivity of conventional groundwater ranges between $(2000-30 \mu \mathrm{s} / \mathrm{cm})$ [9]. The water conductivity of the water samples was measured by a (Multi-Parameter-PCS Testr 35), which was between (1480-978 ms/cm). It was high in water samples with high sulfur content. Total Dissolved Solids (TDS) is all solid materials in ionized and non-ionized solutions do not contain suspended, granular and dissolved gases [10]. The concentration of total dissolved solids in the study area was between (630-666) $\mathrm{mg} / \mathrm{L}$, and when compared with Todd (2005), it was found that the water of the springs of the research area is within the fresh water field. Hardness defined as the concentration of ions found in water that interact with soap to precipitate insoluble residues and precipitate sulphate and carbonate when water boils, measured on the basis of calcium carbonate equivalents [11]. The total hardness (TH) value ranged from $(632.5-516) \mathrm{mg} / \mathrm{L}$, and it was found that the samples are very hard type because of the high percentage of total water shortage in the study area.

\section{2. Chemical properties}

According to Table 1, calcium ion $\left(\mathrm{Ca}^{+2}\right)$ concentrations are between $(168-136) \mathrm{mg} / \mathrm{L}$, where the highest value is in Sheikh Amir village and the lowest value is in the spring number (1). They are within the natural limits according to international standards. $\mathrm{The}_{\mathrm{Mg}} \mathrm{M}^{+2}$ concentrations in the study area were between (62.7-36.2) $\mathrm{mg} / \mathrm{L}$, and the highest value of magnesium ion in spring number (3) while the lowest value in spring number (2). Therefore, the waters of spring No. 3 exceeded the permissible limits according to the international measurements. The value of sodium ion $\left(\mathrm{Na}^{+}\right)$ranges between $(36-11.2) \mathrm{mg} / \mathrm{L}$, and the highest value in the village of Sheikh Amir, while the lowest value in the spring number (2), less than the required quantity according to global measurements. It was found that the concentration of $\mathrm{K}^{+}$was limited to (4.7-1.6) $\mathrm{mg} / \mathrm{L}$, where the highest value was in the village of Sheikh Amir and the lowest value in the spring number (2). Thus, their concentrations are less than the permissible limits compared to global measurements. $\mathrm{SO}_{4}^{-2}$ concentrations ranging between $(342-268) \mathrm{mg} / \mathrm{L}$, thus, all samples of the study exceeded the permissible limit according to the global measurements. The reason for the increase of concentrations to gypsum and anhydrite rocks in the formation of the hole, which is the main source of sulfur ions in the spring's water. The value of chloride ion $\left(\mathrm{Cl}^{-}\right)$is between $(140-26) \mathrm{mg} / \mathrm{L}$, where the highest value was in the village of Sheikh Amir and the lowest value in the spring number (2), which is within the normal limits in all samples of the study according to global measurements. The concentrations of $\mathrm{CO}_{3}^{-2}+\mathrm{HCO}_{3}^{-}$ranged between $(256-196) \mathrm{mg} / \mathrm{L}$, which are within the limits allowed in the study area according to international measurements.

\section{Water classification}

Determining the quality of water is very important for its use for different purposes (human, animal, agricultural), as well as for identifying its sources and inference to its geochemical environment. There are several ways in which the classification of water depending on the chemical components and the most important are:

\section{1. Piper classification, 1944}

The classification of Piper (1944) depends on the chemical components dissolved in water, positive ions (calcium, magnesium, sodium and potassium) and negative ions (sulphate, chloride, carbonate and bicarbonate), and represented both in a diagram with epm measurement. When these two diagrams are combined, a specific form is produced. This form is used to determine the source of these chemical components in the water, as well as the determination of the hydrochemical facies that reflect the rock formation of the contact of these waters with geological formation [12]. The study samples were characterized by the Piper scheme of homogeneity, where it is concentrated in a specific part of the rhombic form (Fig. 4). 


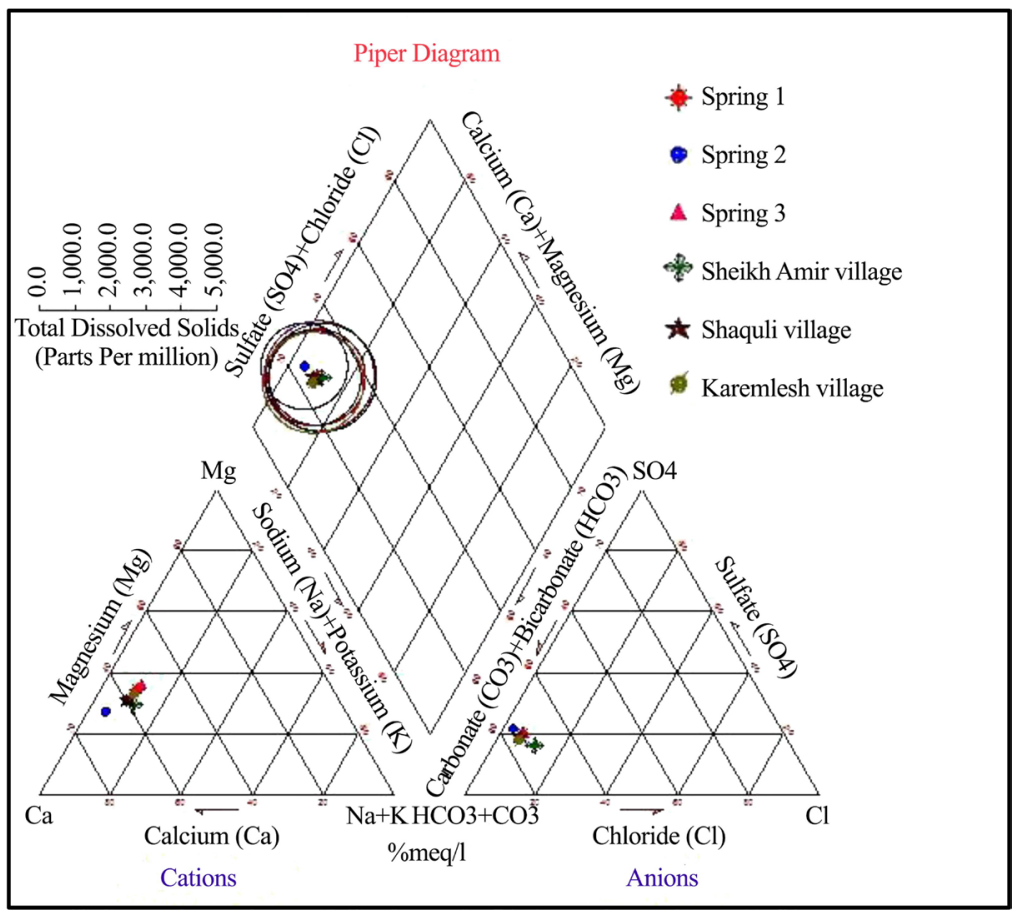

Fig. 4. The projected samples on the Piper diagram [13]

The water quality based on this classification is of the type $\left(\mathrm{Ca}-\mathrm{HCO}_{3}+\mathrm{CO}_{3}\right)$. This indicates that water samples originate from calcareous springs as the groundwater is directly in contact with the calcareous rocks $\left(\mathrm{CaCO}_{3}\right)$ (Fig. 4).

\section{2. Stiff classification, 1951}

In this classification, the positive and negative ions are expressed in order to quantify the concentrations of these ions on horizontal axes parallel to each other. The positive ion concentrates are plotted on the left side and the negative ions on the right side. This classification can determine the ions prevailing in the water samples of the study area (Fig. 5).

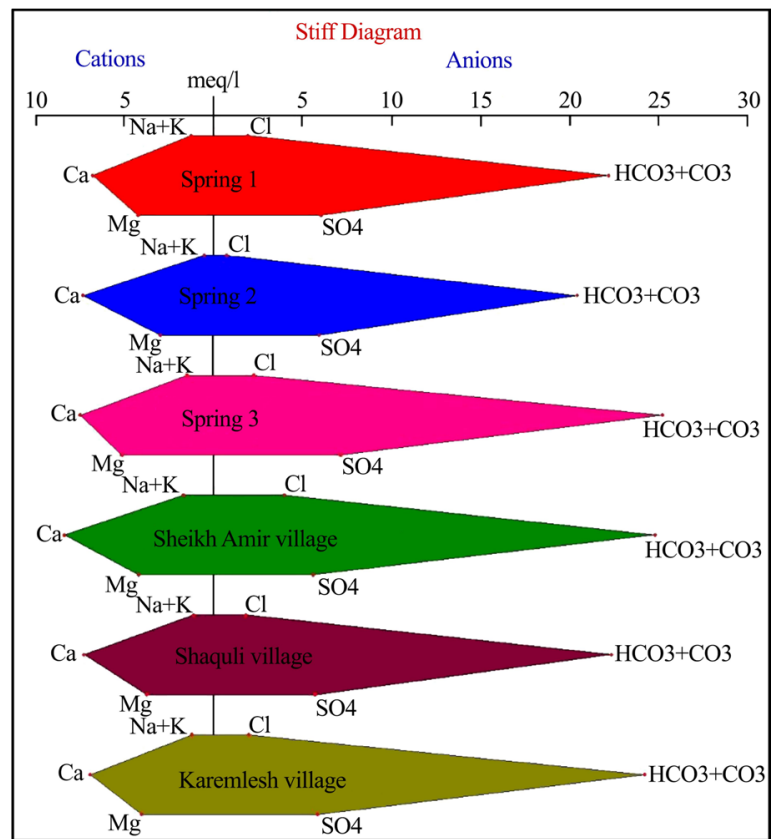

Fig. 5. The projected samples on the Stiff diagram [14] 
The positive and negative ions of water samples were plotted on a Stiff diagram (Fig. 5), and found that the predominant ion is calcium $(\mathrm{Ca})$ for positive ions, and the dominant ion is the carbonates and bicarbonates $\left(\mathrm{HCO}_{3}+\mathrm{CO}_{3}\right)$ for negative ions and this corresponds to the Piper classification, the reason, as it is mentioned earlier, is direct contact of groundwater with limestone rocks $\left(\mathrm{CaCO}_{3}\right)$.

\section{The suitability of the spring water for different uses}

It is the chemical and physical properties of water that determine their suitability for different uses (human, animal, agriculture). To determine the validity of water, its properties must be compared with the international standard properties.

\section{1. The validity of the spring water for human use}

The assessment of water properties is very important for health and for the continuous human use of water. So the chemical and physical concentrations of water must be harmless [15]. In order to determine the validity of use of spring water for human purposes, the international standards were used [16], and compared with the chemical components of water samples (Table 2).

Table 2

Water concentration rates for the study area and comparison with international standards

\begin{tabular}{cccc}
\hline Parameters & Unit & Who 2011 & Samples of water \\
\hline $\mathrm{pH}$ & - & $6.5-8.5$ & $6.8-7.7$ \\
$\mathrm{E} . \mathrm{C}$ & $\mu \mathrm{S} / \mathrm{cm}$ & 300 & $978-1480$ \\
T.H. & $\mathrm{Ppm}$ & $10-500$ & $516-632.5$ \\
T.D.S & $\mathrm{Ppm}$ & $300-1500$ & $630-966$ \\
$\mathrm{Ca}^{+2}$ & $\mathrm{Ppm}$ & $100-200$ & $136-168$ \\
$\mathrm{Mg}^{+2}$ & $\mathrm{Ppm}$ & $30-50$ & $36.2-62.7$ \\
$\mathrm{Na}^{+}$ & $\mathrm{Ppm}$ & $20-175$ & $11.2-36$ \\
$\mathrm{~K}^{+}$ & $\mathrm{Ppm}$ & $10-12$ & $1.6-4.7$ \\
$\mathrm{CaHCO}_{3}^{-}$ & $\mathrm{Ppm}$ & $200-300$ & $196-256$ \\
$\mathrm{SO}_{4}^{-2}$ & $\mathrm{Ppm}$ & $25-250$ & $268-342$ \\
$\mathrm{Cl}^{-}$ & $\mathrm{Ppm}$ & $25-200$ & $26-140$
\end{tabular}

It was observed that the main ions (negative and positive) are within the standard specifications except for sulfur sulphate $\left(\mathrm{SO}_{4}\right)$ which is higher than the desired specifications for human use of water because melting of gypsum and anhydrite rocks in Fat'ha formation, in addition to high electrical conductivity and total hardness because increase of sulphates and carbonates and this applies to spring number (3). Spring number (2) is considered the best spring for human use because the properties of water are within the international specifications.

\section{2. The validity of the spring water for agricultural use}

The values of electrical conductivity (EC) can be used to determine the validity of water for use in agriculture through the tolerance of plants to salts, as in the division of Todd [8], where crops are divided into three groups: fruits, vegetables, field crops, and three levels (Table 3). This classification shows that all water samples of the study area are suitable for all types of agricultural crops (Fig. 6).

In addition, the Wilcox classification was used to determine the validity of the water of the area for irrigation based on the values of both the electrical conductivity (EC) and the 
percentage of sodium ions ( $\mathrm{N} \%$ ). The percentage values of sodium ions were extracted by the following equation [8]:

$$
\mathrm{Na} \%=\frac{r \mathrm{Na}}{r(\mathrm{Ca}+\mathrm{Mg}+\mathrm{Na}+\mathrm{K})} \cdot 100 .
$$

Table 3

The amount of agriculture tolerances for concentration of salts [8]

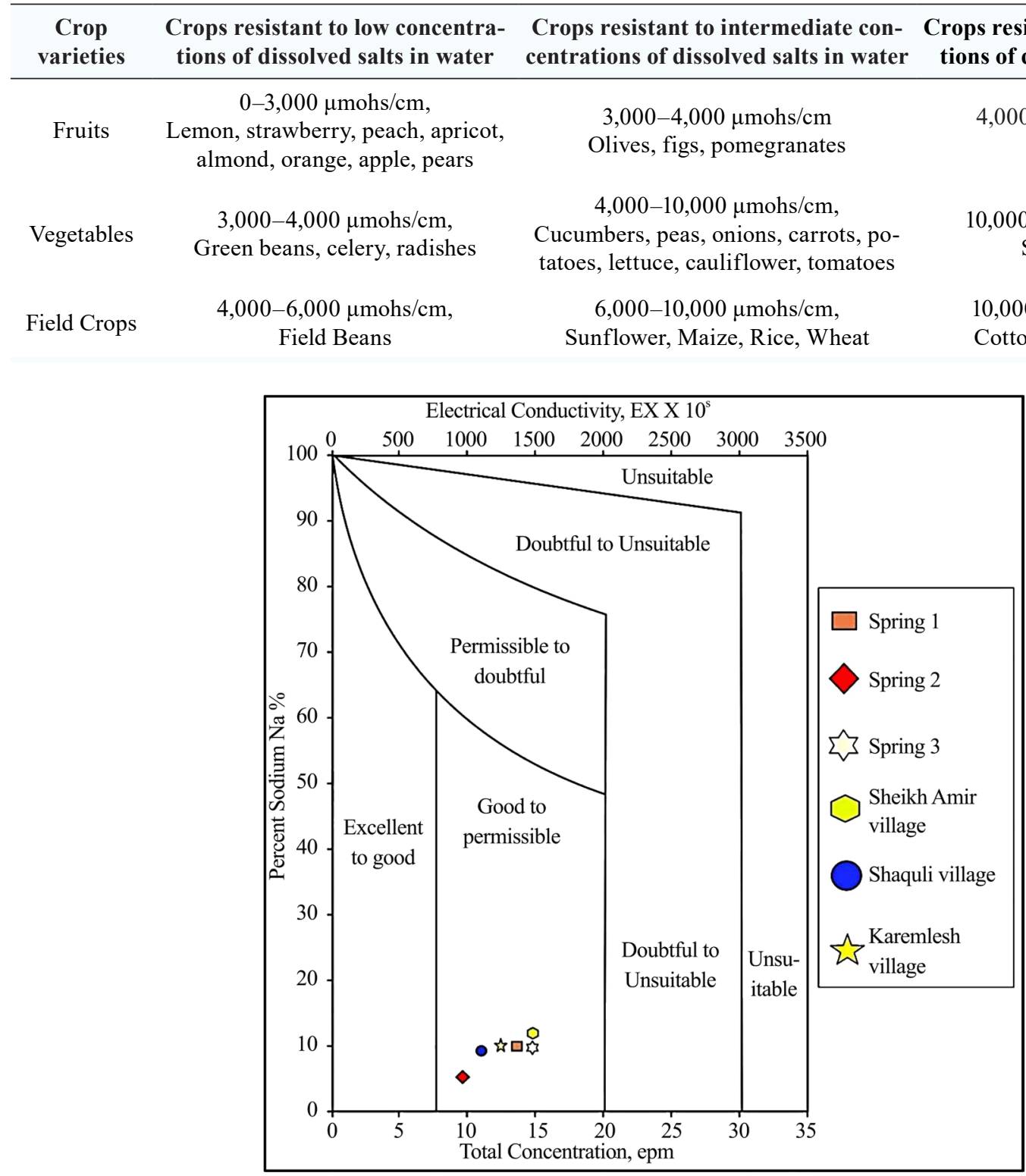

Fig. 6. The projected samples in the Wilcox scheme [17]

Fig. 6 shows that the water samples of the study area are within the field (good - permissible) and therefore are suitable for irrigation according to Wilcox classification.

\section{3. The validity of the spring water for animal use}

The proposed specifications were used by [18] based on positive and negative ions, soluble salts and total hardness (Table 4). 
Table 4

Water specifications for animal use [18]

\begin{tabular}{cccccc}
\hline Parameters Ppm & Very good water & Good & Water acceptable & Can be use & Upper limit \\
\hline T.H. & 1500 & 3200 & 4000 & 4700 & 54000 \\
T.D.S & 3000 & 5000 & 7000 & 10000 & 15000 \\
$\mathrm{Ca}^{+2}$ & 350 & 700 & 800 & 900 & 1000 \\
$\mathrm{Mg}^{+2}$ & 150 & 350 & 500 & 600 & 700 \\
$\mathrm{Na}^{+}$ & 800 & 1500 & 2000 & 2500 & 4000 \\
$\mathrm{SO}_{4}^{-2}$ & 1000 & 2500 & 3000 & 4000 & 6000 \\
$\mathrm{Cl}^{-}$ & 900 & 2000 & 3000 & 4000 & 6000
\end{tabular}

It was shown by comparison with Table 4 that the water samples of the study area are suitable for use and for all species of animals and to an excellent degree.

\section{Recommendations}

1. Conducting hydrochemical analysis during all seasons of the year, in order to identify the change in concentration between seasons and the extent of the effect of this change on different uses.

2. Urge residents of Tarjla village to use the water of spring No. (2) for drinking purposes and avoid using springs (1) and (3).

3. Organizing educational workshops in which residents of the study area are invited to make sure to avoid dumping of waste and sewage to the concrete waterway extending to Karemlesh village to protect it from pollution.

4. Urge government agencies to pay attention to the three springs, especially spring No. (1), which uses its water to treat skin diseases, to make ownership of the springs belong to the Ministry of Irrigation and regulate the distribution of water among the beneficiaries.

5. Conducting hydrogeological studies on the aquifers from which the springs originate.

6. There are many chemical elements recommended by researchers for their study which have a significant impact on the deterioration of human health such as lead, copper, arsenic, barium and cyanide.

\section{Conclusions}

The results of the physical and chemical analysis of the three spring waters show that spring No. 1 and spring No. 3 originate from the Fat'ha formation that contains limestone and gypsum rocks containing high concentrations of sulphates, while spring No. 2 stems from the Injana formation and Quaternary sediments that hydraulically connected with each other and can be considered a single aquifer.

It is clear from the Piper and Stiff classifications that all the water samples of the type of calcium - bicarbonate, noting that the calcium ion predominates on the rest of the positive ions, and the bicarbonate ion predominates on the rest of the negative ions, this shows that calcium bicarbonate $\left(\mathrm{Ca}\left(\mathrm{HCO}_{3}\right)_{2}\right)$ is common in water samples.

The water quality in the water samples is very hard (type of permanent hardness), due to the high concentration of calcium and magnesium ions because of the melting of gypsum, anhydrite and limestone rocks found within the geological formations in the study area. The hardness values ranged between (632.5-516) $\mathrm{mg} / \mathrm{L}$.

The flow of water in some springs led to a difference in the ratio of physical and chemical concentrations in terms of increase and decrease. For example, the spring No. (3) when the water reached the village of Sheikh Amir for a distance of (1.24), where increased concentration of turbidity, PH, soluble solids, calcium, sodium, potassium and chlorine, and decreased concentrations of total hardness, magnesium, bicarbonate and sulfate, The reason for this is the flow of water within the valley and the contents of this valley of different types of rocks, soil and plants affected 
the proportion of water concentrations. As for the water of the springs No. (1) and (2) and when compared with water in the villages of Shaquli and Karemlesh, it is noted that flowing water for a distance of (6.25) $\mathrm{km}$ did not affect the concentrations of large, the reason is the flow of water within a concrete waterway from the bottom and from the sides.

Comparison of the results of spring's water analyses with international standards showed that spring No. (2) is the best spring for human use, while spring No. (3) is one of the worst spring and is not suitable for human use because it contains a high percentage of sulphates. The three spring are suitable for agricultural and animal use.

It was found that the spring No. (3) water is suitable for agricultural and animal use according to the Wilcox classification.

\section{References}

[1] Al-Manmi, D. A. (2007). Groundwater Quality Evaluation in Kalar Town-Sulaimani/NE -Iraq. Iraqi Journal of Earth Sciences, 7 (2), 31-52.

[2] Winquist, F., Olsson, J., Eriksson, M. (2011). Multicomponent analysis of drinking water by a voltammetric electronic tongue. Analytica Chimica Acta, 683 (2), 192-197. doi: https://doi.org/10.1016/j.aca.2010.10.027

[3] Eklemis, Y. F., Hasan, A. A. (2005). Using GMS to Formulate the Geological Sections for Hamdania Region, North Iraq. Rafidain Journal of Science, 16 (2), 176-190.

[4] Al- Noaimie, F. H. (2010). Study and Mathematical Modelling for Ground Water Aquifers in Middle Part of the East Ninevah Basin. College of Scince, University of Mosul, 155.

[5] AlSayegh, A. H. Y., Yousif, K. H. (2006). The Effect of Using the Waters of Ain Alsafra Spring on Jaundice Disease / Northen Iraq. Iraqi National Journal of Earth Science, 6 (2), 45-56.

[6] APHA, AWWA and WPCF (1995). Standard methods for the examination of water and wastewater. American Public Health Association, Publication Office, Washington D.C., 759.

[7] Boyd, C. E. (2000). Water Quality. An Introduction. Springer, 330. doi: https://doi.org/10.1007/978-1-4615-4485-2

[8] Todd, D. K. (1980). Groundwater Hydrology. John Wiley, 535.

[9] Davis, S. N., Dewiest, R. J. (1966). Hydrogeology. John Wiley and Sons, 463.

[10] Micheal, A. M., Khepar, S. D. (1989). Water well and pump engineering. Tata McGraw-Hill Publishing Co., Ltd., New Delhi, 923.

[11] Todd, D. K., Mays, L. W. (2005). Groundwater Hydrology. John Wiley and Sons, 656.

[12] Fetter, C. W. (1980). Applied Hydrogeology. Columbus C. E. Merrill, 488.

[13] Piper, A. M. (1944). A graphic procedure in the geochemical interpretation of water-analyses. Transactions, American Geophysical Union, 25 (6), 914. doi: https://doi.org/10.1029/tr025i006p00914

[14] Stiff, H. A. (1951). The Interpretation of Chemical Water Analysis by Means of Patterns. Journal of Petroleum Technology, 3 (10). doi: https://doi.org/10.2118/951376-g

[15] Alloway, B., Ayres, D. C. (1997). Chemical Principles of Environmental Pollution. Chapman and Hall, 395.

[16] WHO (2011). Guidelines for drinking-water quality, 3rd edition: Volume 1 - Recommendations. Geneva, 668.

[17] Wilcox, L. V. (1955). Classification and use of irrigation water. USDA circular 969, 19.

[18] Altoviski, M. E. (1962). Handbook of Hydrogeology. Moscow, 614. 